\title{
School of Economics
}

\section{Relationship Lending during a Trust Crisis on the Interbank Market}

A Friend in Need is a Friend Indeed

\author{
Hans Degryse \\ Alexei Karas \\ Koen Schoors
}


Utrecht University School of Economics (U.S.E.) is part of the faculty of Law, Economics and Governance at Utrecht University. The U.S.E. Research Institute focuses on high quality research in economics and business, with special attention to a multidisciplinary approach. In the working papers series the U.S.E. Research Institute publishes preliminary results of ongoing research for early dissemination, to enhance discussion with the academic community and with society at large.

The research findings reported in this paper are the result of the independent research of the author(s) and do not necessarily reflect the position of U.S.E. or Utrecht University in general. 


\title{
School of Economics
}

U.S.E. Research Institute

Working Paper Series 19-04

\section{Relationship Lending during a Trust Crisis on the Interbank Market: A Friend in Need is a Friend Indeed}

\author{
Hans Degryse \\ Department of Accounting, Finance and Insurance, \\ KU Leuven \\ Alexei Karas \\ Department of Social Science, University \\ College Roosevelt \\ Utrecht School of Economics \\ Utrecht University \\ Koen Schoors \\ Department of Economics \\ Ghent University
}

January 2019

\begin{abstract}
We exploit uncertainty regarding banks' involvement in money laundering activities as a natural experiment to study the functioning of the interbank market in uncertain times. We show that bank couples with a stronger relationship (i.e., more frequent and reciprocal interactions before the event) are more likely to continue lending to one another, and at lower interest rates. This is in line with a "helping hand" or "flight to friends" hypothesis during crisis.
\end{abstract}

Keywords: banks, interbank market, relationship banking, helping-hand hypothesis

JEL classification: G21

Acknowledgements:

Comments welcomed to: $\underline{\text { Hans.Degryse@kuleuven.be ; A.Karas@ucr.nl ; Koen.Schoors@UGent.be }}$ 


\section{Introduction}

There is growing body of literature on the existence and nature of relationship lending in interbank markets in normal and crisis times (Cocco et al., 2009; Afonso et al., 2011; Affinito, 2012; Craig et al., 2015; Bräuning and Fecht, 2016). ${ }^{1}$ The empirical work on the role of relationships during crisis times however faced the challenge that relationships themselves may change due to the fundamentals of banks being affected by the underlying economic conditions. In this paper, we circumvent this challenge by exploiting a natural experiment that generated uncertainty on the Russian interbank market but without being related to the economic fundamentals: the withdrawal of one bank's license on the grounds of money laundering and rumours about a blacklist of banks awaiting license withdrawal for the same reason. Strong relationships may be a helping hand in such a crisis environment since relationship lenders have private information at their disposal about their counterparties. This private information is non-observable to unrelated transactional lenders.

The closest paper to ours is Bräuning and Fecht (2016). They empirically investigate the effect of relationship lending on the availability and price of interbank liquidity in a panel of unsecured overnight loans between German bank pairs from March 2006 to November 2007. Relationship lenders improve the availability of credit to related borrowers and are more likely to provide liquidity to them, and at cheaper rates during crisis. They also show that relationship lenders already adjust their loan terms in the run-up to the interbank crisis. We contribute to this work by exploiting an exogenous shock to the mutual trust in the Russian interbank market stemming from uncertainty about involvement in money laundering and potential license withdrawal. Using a rich and complete dataset of all Russian individual interbank lending contracts covering a window around the exogenous event, we find that banks after the event have a higher likelihood to still receive loans from other banks with whom they have strong relationships, and at lower interest rates, relative to the pre-crisis period and relative to loans from transactional banks. This is consistent with a "helping hand" or "flight to friends" hypothesis.

\section{Event and Data Description}

In May 2004, a crisis on the Russian interbank market was triggered. In particular, on May 13 the Central Bank of Russia recalled the license from Sodbiznesbank on accusations of money laundering and sponsorship of terrorism. It was the first bank to be closed on these grounds in Russia. This unexpected closure caused panic on the interbank market since banks suspected other banks would follow suit, but they had no reliable information on who these banks might be. On May 16 the head of Federal Financial Monitoring Service, Viktor Zubkov, announced publicly that his agency suspected another ten banks of similar violations. Because this announcement was not accompanied by the actual list of suspected banks, it just fuelled the hysteria on the interbank market. Rumours about the identities of these ten banks started to spread rapidly. Soon several inconsistent blacklists were circulating in the banking community as bankers tried to guess which banks were officially suspected of money laundering. Anecdotal evidence suggests that banks were actively helping to

\footnotetext{
${ }^{1}$ The literature on relationship lending started of in the corporate loan markets. Banks gather information over time and across products about their corporate borrowers. For a review, see Boot (2000), or Kysucky and Norden (2015).
} 
spread the rumour by removing themselves from the list and adding competitors in an attempt to escape the carnage. By consequence, the union of all the blacklists circulating in the banking community expanded in a few days to include dozens of banks, including several market leaders.

In the presence of total uncertainty about the quality of their counterparties, banks began to reduce limits on each other, which reverberated into an acute liquidity drought on the interbank market (Paranyushkin, 2009). The turnover volume on the interbank market dropped spectacularly. Later the original source of the panic, Viktor Zubkov, shockingly announced that "the Federal Financial Monitoring Service has no blacklist". The deputy Minister of Internal Affairs similarly announced that "the Interior Ministry has no such list. We have no plans to persecute any banks." ${ }^{2}$ Up till now it remains unclear whether an official list actually existed. Important for our identification strategy, the 2004 meltdown on the Russian interbank market was fully based on rumours and unrelated to shocks to the fundamentals of Russian banks or the Russian economy at large. This makes it an almost perfect natural experiment, because it provides us with a non-fundamental and exogenous mutual trust crisis. We use this to answer the research question whether (stronger) relationships may provide insurance against the impact of such events.

We use contract data on the Russian interbank market. Every month Russian banks must inform the Central Bank of Russia about their interbank activities using a standard form 0409501 "On Interbank Loans and Deposits". We purchased these data from a private financial information agency Mobile (www.mobile.ru) for the period from July 1998 to October 2004. Each contract identifies the issuer of the loan, the receiver, the reporting month, the beginning and the end of month balances, the debit and credit turnovers, the interest rate, the maturity date, and the maturity bucket. Vandermarliere et al. (2015) provide a complete and detailed description of the data and complement this with an analysis of its implied network characteristics.

The maturity buckets in the contract data are: 1 day, 2-7 days, 8-30 days, 31-90 days, 91-180 days, 181 day - 1 year, 1-3 years, more than 3 years, and demand. The loan issuance date is not reported but can be reconstructed for 1-day loans as: Issue Date $=$ Maturity Date -1 . Because we need to know whether the loan is issued before or after the start of the crisis, we limit our analysis to 1-day loans. In addition, we drop loans from/to foreign banks. ${ }^{3}$ For these banks we can't construct relationship measures, because they lack consistent identifiers in our database. ${ }^{4}$ Finally, we limit the sample to banks with an active banking license as of the 1st of May 2004.

Figure 1 shows the average 1-day interbank interest rates in May 2004. Gray (resp. black) bars represent the period before (resp. after) the start of the crisis. The date on the vertical axis is the loan maturity date. Because 1-day loans do not mature in the weekend, on a holiday, or on the first day thereafter, these days are missing from the figure. In addition, we drop loans maturing on May 14: those loans were issued on May 13, but we don't know whether they were issued before or after the Sodbiznesbank's closure announcement. We clearly observe that rates went up considerably in the first weeks after the event.

\footnotetext{
${ }^{2}$ For further descriptions (in Russian) of this episode in Russian history see Simonov (2009); Boyarskiy (2018).

${ }^{3}$ In April 2004, 1-day loans received from foreign banks represented 2.5\% of all received 1-day loans (13\% in terms of volume). Numbers are comparable throughout the rest of 2004.

${ }^{4}$ Specifically, the spelling of foreign bank names varies wildly across counterparties and over time.
} 


\section{Methodology}

We employ a difference-in-difference approach to study whether relationships help in mitigating the impact generated by the natural experiment. In particular, we estimate the following two equations on daily bank pair data for May 2004:

$$
\begin{aligned}
& D_{i j t}=\beta_{0}+\beta_{1} R_{i j}+\beta_{2} R_{i j} C+F E+e_{i j t} \\
& i_{l i j t}=\beta_{0}+\beta_{1} R_{i j}+\beta_{2} R_{i j} C+F E+e_{l i j t}
\end{aligned}
$$

$D_{i j t}$ equals 1 if banks $i$ and $j$ have at least one outstanding 1-day loan between them on day $t$ and 0 otherwise. $i_{\text {lijt }}$ is the interest rate on 1-day interbank loan $l$ from bank $i$ to bank $j$ maturing on day $t$. We add the index $l$ because bank couples $i j$ can issue multiple 1-day loans on the same day. $R_{i j}$ stands for one of the two measures of relationship intensity between banks $i$ and $j$. The first measure is interaction frequency, $R^{f}$. It is defined as the natural logarithm of 1 plus the number of 1-day loans issued between banks $i$ and $j$ during the year 2003. This indicator stems from the relationship lending literature where it is argued that banks gather more private information about each other by transacting more frequently. We take the log to make the distribution less skewed.

The second measure is reciprocity, $R^{r}$. We define $R^{f 1}$ (resp. $R^{f 2}$ ) as the number of 1-day loans from bank $i$ to bank $j$ (resp. from $j$ to $i$ ) issued in the year 2003. We then take twice the minimum of $R^{f 1}$ and $R^{f 2}$, and divide by their sum:

$$
R^{r}=2 \frac{\min \left(R^{f 1}, R^{f 2}\right)}{R^{f 1}+R^{f 2}}
$$

$R^{r}$ varies from 0 to 1 ; it equals 0 for an entirely one-way relationship in which either $R^{f 1}=0$ or $R^{f 2}=0$; it equals 1 for a perfectly symmetric relationship where $R^{f 1}=R^{f 2}$. Reciprocity is specific to the interbank market as banks can both be borrowing from and lending to each other. A higher reciprocity may reflect greater mutual trust between banks.

The post-crisis dummy $C$ equals 1 from May 18, 2004 onward, which is the first day on which contracts issued after the event mature. Our "flight to friends" hypothesis is that in crisis times banks have a higher likelihood to receive loans from relationship banks, and at lower interest rates, relative to the pre-crisis period and relative to loans from transactional banks. In line with this hypothesis, we expect $\beta_{2}$ to be positive in equation 1 and negative in equation 2 .

$F E$ stands for various combinations of time and bank fixed effects. In the most demanding specifications, we include day $t$, lender $i$ and borrower $j$ fixed effects. Standard errors are two-way clustered at the level of both banks $i$ and $j$ using Stata routine reghdfe (Correia, 2016).

\section{Results}

Table 1 reports the results of estimating equation 1, which predicts whether bank pairs are active on the 1-day loan market on day $t$. In these regressions, we only include bank pairs which had at least one outstanding 1-day loan between January 1, 2003 and May 31, 2004. We report specifications 
with day (columns 1, 3 and 5), as well as with day, lender and borrower (columns 2, 4 and 6) fixed effects. As a relationship indicator, we use interaction frequency $R^{f}$ (columns 1 and 2), reciprocity $R^{r}$ (columns 3 and 4 ), or both (columns 5 and 6). Table 1 reveals that bank couples with a stronger relationship in 2003 have a higher likelihood to have an outstanding interbank loan in May 2004. For example, using estimates in column 2 (4), we find that a one standard deviation increase in $R^{f}\left(R^{r}\right)$ raises the likelihood of having a bank pair active on any particular day by 2.4 (1.3) percentage points. More importantly, we find that this effect is stronger during the crisis (i.e., when $C=1$ ). Across all six specifications, the interactions of our relationship measures with the post-crisis dummy $C$ are positive and significant. That is, strong past relationships increase the likelihood of banks teaming up during the crisis, in line with a "helping hand" effect.

Table 2 reports the results of estimating equation 2. We find no evidence that stronger relationships influence interest rates in normal times. However, bank couples with stronger relationships do charge each other lower rates in the period when there is uncertainty in the interbank market (i.e., when $C=1)$. Using estimates in column $2(4)$, we find that a one standard deviation increase in $R^{f}\left(R^{r}\right)$ leads to a $28(27)$ basis points lower interest rate during the crisis compared to the normal period. Our results hold controlling for several sets of fixed effects. Columns 5 and 6 report the results when including both relationship variables. While somewhat weaker, our main findings continue to hold. In sum, our findings are consistent with a "helping hand" or "flight to friends" effect in times of uncertainty on the interbank market.

\section{Conclusion}

Our results provide evidence for the thesis that bank couples with a strong relationship provide a "helping hand" in times of an exogenous crisis of trust. We exploit the uncertainty created by one bank losing its license on accusations of money laundering and rumours of more banks to follow, as a natural experiment: in response to this money laundering related uncertainty the level of mutual bank trust dropped abruptly, without any preceding change in bank fundamentals.

We show that bank couples with an ex-ante stronger relationship, as measured by the frequency and reciprocity of their daily interactions on this market, exhibit an increased likelihood of lending to one another in times of crisis and a lower interest rate at which this crisis time lending occurs, relative to these banks' contracts with other non-related banks and to non-crisis periods. In sum, "a friend in need is a friend indeed".

\section{References}

Affinito, M. (2012). Do interbank customer relationships exist? And how did they function in the crisis? Learning from Italy. Journal of Banking \& Finance, 36(12):3163-3184.

Afonso, G., Kovner, A., and Schoar, A. (2011). Stressed, not frozen: The federal funds market in the financial crisis. The Journal of Finance, 66(4):1109-1139.

Boot, A. W. (2000). Relationship banking: What do we know? Journal of financial intermediation, $9(1): 7-25$. 
Boyarskiy, A. (2018). Modern Russian Banking System. Brief Chronology. Period 1988-2004.

Bräuning, F. and Fecht, F. (2016). Relationship lending in the interbank market and the price of liquidity. Review of Finance, 21(1):33-75.

Cocco, J. F., Gomes, F. J., and Martins, N. C. (2009). Lending relationships in the interbank market. Journal of Financial Intermediation, 18(1):24-48.

Correia, S. (2016). REGHDFE: Stata module to perform linear or instrumental-variable regression absorbing any number of high-dimensional fixed effects. Statistical Software Components.

Craig, B. R., Fecht, F., and Tümer-Alkan, G. (2015). The role of interbank relationships and liquidity needs. Journal of Banking \& Finance, 53:99-111.

Kysucky, V. and Norden, L. (2015). The Benefits of Relationship Lending in a Cross-Country Context: A Meta-Analysis. Management Science, 62(1).

Paranyushkin, D. (2009). Russian Money Market \& Bank System: Problems.

Simonov, N. S. (2009). Banks and Money, 1988-2008. RAGS.

Vandermarliere, B., Karas, A., Ryckebusch, J., and Schoors, K. (2015). Beyond the power law: Uncovering stylized facts in interbank networks. Physica A: Statistical Mechanics and its Applications, 428:443-457.

\section{Tables and Figures}




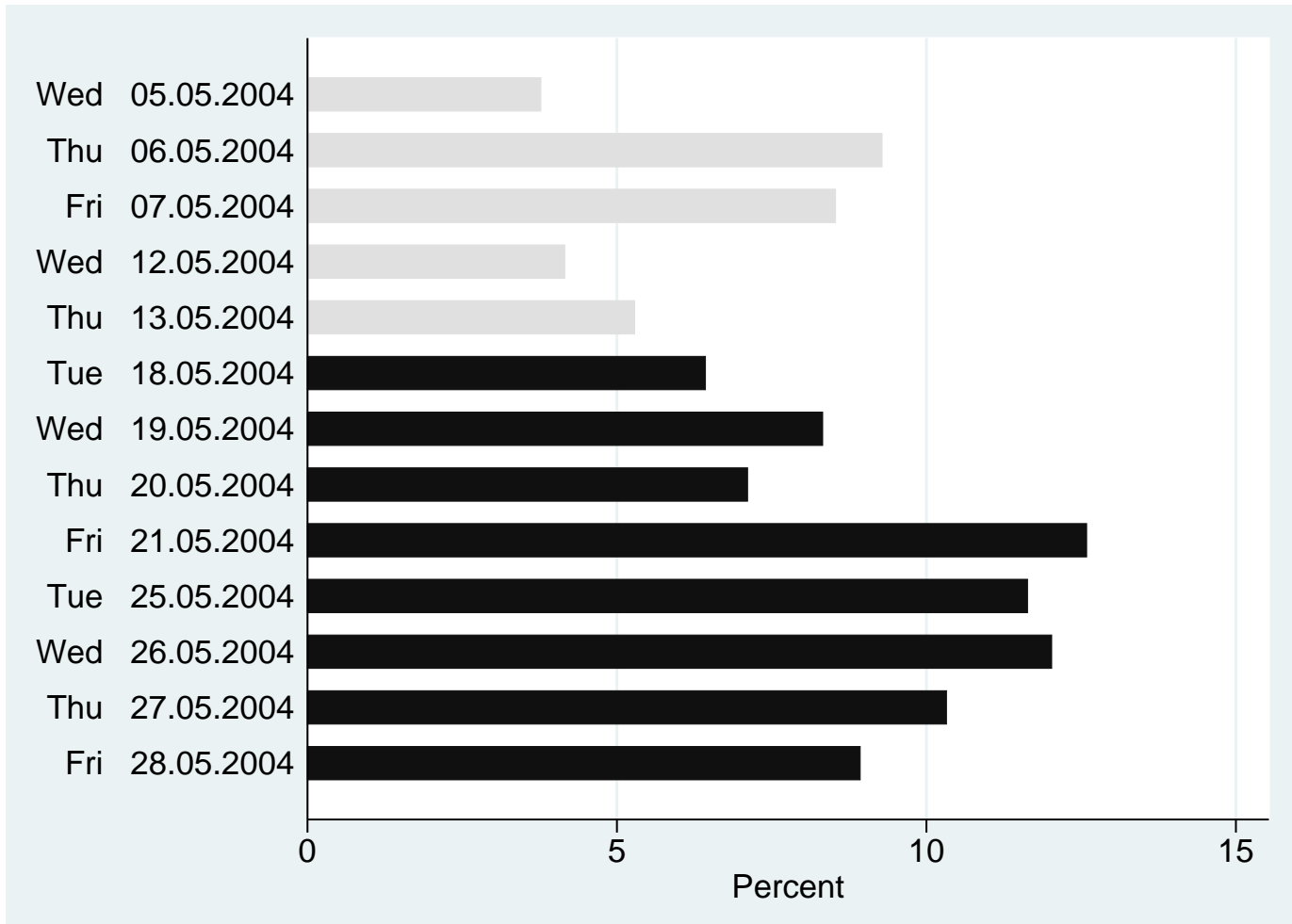

Figure 1. Average 1-day Interbank Rate in May 2004 
Table 1. Estimation Results for Equation 1

$$
D_{i j t}=\beta_{0}+\beta_{1} R_{i j}+\beta_{2} R_{i j} C+F E+e_{i j t}
$$

$D_{i j t}$ is defined for banks $i$ and $j$ that had at least one outstanding 1-day loan during 1Jan2003-31May2004: $D_{i j t}=\left\{\begin{array}{l}1 \text { if banks } i \text { and } j \text { have an outstanding 1-day loan on day } t ; \\ 0 \text { otherwise. }\end{array}\right.$

$R_{i j}$ is a measure of a relationship between banks $i$ and $j$. Post-crisis dummy $C$ equals 1 from May 18, 2004 onward. FE stands for various combinations of time and bank fixed effects reported in the table. Standard errors are two-way clustered at the level of both banks $i$ and $j$. ${ }^{* * *} \mathrm{p}<0.01,{ }^{* *} \mathrm{p}<0.05,{ }^{*} \mathrm{p}<0.1$

\begin{tabular}{|c|c|c|c|c|c|c|}
\hline & (1) & $(2)$ & (3) & (4) & (5) & (6) \\
\hline VARIABLES & $D$ & $D$ & $D$ & $D$ & $D$ & $D$ \\
\hline$R^{f}$ & $\begin{array}{c}0.02^{* * *} \\
(0.002)\end{array}$ & $\begin{array}{c}0.02^{* * *} \\
(0.001)\end{array}$ & & & $\begin{array}{c}0.02^{* * *} \\
(0.002)\end{array}$ & $\begin{array}{c}0.02^{* * *} \\
(0.001)\end{array}$ \\
\hline$R^{f} C$ & $\begin{array}{c}0.009^{* * *} \\
(0.001)\end{array}$ & $\begin{array}{c}0.009^{* * *} \\
(0.001)\end{array}$ & & & $\begin{array}{c}0.008^{* * *} \\
(0.002)\end{array}$ & $\begin{array}{c}0.008^{* * *} \\
(0.002)\end{array}$ \\
\hline$R^{r}$ & & & $\begin{array}{c}0.03^{* * *} \\
(0.004)\end{array}$ & $\begin{array}{c}0.04^{* * *} \\
(0.004)\end{array}$ & $\begin{array}{c}-0.02^{* * *} \\
(0.004)\end{array}$ & $\begin{array}{l}0.005 \\
(0.003)\end{array}$ \\
\hline$R^{r} C$ & & & $\begin{array}{c}0.02^{* * *} \\
(0.004)\end{array}$ & $\begin{array}{c}0.02^{* * *} \\
(0.004)\end{array}$ & $\begin{array}{c}0.008^{* *} \\
(0.004)\end{array}$ & $\begin{array}{c}0.008^{* *} \\
(0.004)\end{array}$ \\
\hline Time FE & Yes & Yes & Yes & Yes & Yes & Yes \\
\hline Borrower FE & & Yes & & Yes & & Yes \\
\hline Lender FE & & Yes & & Yes & & Yes \\
\hline Observations & 351,117 & 351,117 & 351,117 & 351,117 & 351,117 & 351,117 \\
\hline$R^{2}$ & 0.027 & 0.087 & 0.012 & 0.080 & 0.027 & 0.087 \\
\hline
\end{tabular}


Table 2. Estimation Results for Equation 2

$$
i_{\text {lijt }}=\beta_{0}+\beta_{1} R_{i j}+\beta_{2} R_{i j} C+F E+e_{l i j t}
$$

$i_{\text {lijt }}$ is the interest rate on a 1-day interbank loan $l$ from bank $i$ to $j$ maturing on day $t$. $R_{i j}$ is a measure of a relationship between banks $i$ and $j$. Post-crisis dummy $C$ equals 1 from May 18, 2004 onward. $F E$ stands for various combinations of time and bank fixed effects reported in the table. Standard errors are two-way clustered at the level of both banks $i$ and $j$. *** $\mathrm{p}<0.01,{ }^{* *} \mathrm{p}<0.05,{ }^{*} \mathrm{p}<0.1$

\begin{tabular}{lcccccc}
\hline & $(1)$ & $(2)$ & $(3)$ & $(4)$ & $(5)$ & $(6)$ \\
VARIABLES & $i$ & $i$ & $i$ & $i$ & $i$ & $i$ \\
\hline \multirow{7}{*}{$R^{f}$} & 0.007 & -0.04 & & & 0.07 & -0.08 \\
& $(0.10)$ & $(0.05)$ & & & $(0.1)$ & $(0.07)$ \\
$R^{f} C$ & $-0.2^{* * *}$ & $-0.2^{* * *}$ & & & $-0.2^{*}$ & -0.09 \\
& $(0.08)$ & $(0.06)$ & & & $(0.09)$ & $(0.07)$ \\
$R^{r}$ & & & -0.6 & 0.2 & -0.7 & 0.4 \\
& & & $(0.4)$ & $(0.2)$ & $(0.5)$ & $(0.3)$ \\
$R^{r} C$ & & & $-1.1^{* * *}$ & $-0.8^{* * *}$ & $-0.8^{* *}$ & $-0.6^{* *}$ \\
& & & $(0.4)$ & $(0.3)$ & $(0.4)$ & $(0.3)$ \\
& & & & & & \\
Time FE & Yes & Yes & Yes & Yes & Yes & Yes \\
Borrower FE & & Yes & & Yes & & Yes \\
Lender FE & & Yes & & Yes & & Yes \\
Observations & 13,397 & 13,213 & 13,397 & 13,213 & 13,397 & 13,213 \\
$R^{2}$ & 0.197 & 0.621 & 0.201 & 0.621 & 0.202 & 0.621 \\
\hline
\end{tabular}




\section{Appendix A. Summary Statistics}

Table A.1. Summary Statistics for Equation 1

\begin{tabular}{lcccccccccc}
\hline & $(1)$ & $(2)$ & $(3)$ & $(4)$ & $(5)$ & $(6)$ & $(7)$ & $(8)$ & $(9)$ & $(10)$ \\
VARIABLES & $\mathrm{N}$ & mean & $\mathrm{sd}$ & $\mathrm{min}$ & $\mathrm{p} 1$ & $\mathrm{p} 25$ & $\mathrm{p} 50$ & $\mathrm{p} 75$ & $\mathrm{p} 99$ & $\max$ \\
\hline & & & & & & & & & & \\
$D_{i j t}$ & 351,117 & 0.070 & 0.26 & 0 & 0 & 0 & 0 & 0 & 1 & 1 \\
$R^{f}$ & 351,117 & 1.93 & 1.21 & 0 & 0 & 0.69 & 1.95 & 2.83 & 4.51 & 5.99 \\
$R^{r}$ & 351,117 & 0.23 & 0.33 & 0 & 0 & 0 & 0 & 0.48 & 1 & 1 \\
& & & & & & & & & & \\
\hline
\end{tabular}

Table A.2. Summary Statistics for Equation 2

\begin{tabular}{lcccccccccc}
\hline & $(1)$ & $(2)$ & $(3)$ & $(4)$ & $(5)$ & $(6)$ & $(7)$ & $(8)$ & $(9)$ & $(10)$ \\
VARIABLES & $\mathrm{N}$ & mean & $\mathrm{sd}$ & $\mathrm{min}$ & $\mathrm{p} 1$ & $\mathrm{p} 25$ & $\mathrm{p} 50$ & $\mathrm{p} 75$ & $\mathrm{p} 99$ & $\max$ \\
\hline & & & & & & & & & & \\
$i_{\text {lijt }}$ & 13,397 & 8.93 & 5.70 & 0 & 0 & 5 & 8.76 & 13 & 25 & 55 \\
$R^{f}$ & 13,397 & 2.56 & 1.41 & 0 & 0 & 1.79 & 2.83 & 3.61 & 5.29 & 5.99 \\
$R^{r}$ & 13,397 & 0.30 & 0.34 & 0 & 0 & 0 & 0.13 & 0.59 & 1 & 1 \\
& & & & & & & & & & \\
\hline
\end{tabular}

